\title{
Analysis of the Relationship between Lifestyle and Coffee Consumption Habits, from the Myth Approach, in the Municipalities of Orizaba, Tehuipango, and Zongolica Veracruz.
}

\author{
Rogelio Limón-Rivera ${ }^{1}$, Francisco Javier Mejía-Ochoa², Elyana Cristina Peláez-Muñoz ${ }^{3}$, \\ Yamill Vargas-Rivera ${ }^{4}$, Silvia Hernández-Velásquez ${ }^{5}$, Evaristo Fierro-Domínguez ${ }^{6}$, \\ Laura Castro-Medina ${ }^{7}$; Manuel González-Pérez ${ }^{8}$
}

\footnotetext{
${ }^{1}$ Teacher-researcher at Instituto Tecnológico Superior de Zongolica \& Ph.D. student in Strategic Management Sciences at Colegio Interdisciplinario de Especialización A. C. (CIES).

Email: rogelio_limon_pd105@itszongolica.edu.mx

${ }^{2}$ Teacher-researcher at Instituto Tecnológico Superior de Zongolica \& Ph.D. student in Strategic Management Sciences at Colegio Interdisciplinario de Especialización A. C. (CIES).

Email: francisco_javier_mejia_125@itszongolica.edu.mx

${ }^{3} \mathrm{Ph} . \mathrm{D}$. student in Strategic Management Sciences at Colegio Interdisciplinario de Especialización A. C. (CIES) Email: elyana19@hotmail.com

${ }^{4} \mathrm{Ph} . D$. student in Strategic Management Sciences at Colegio Interdisciplinario de Especialización A. C. (CIES) Email: yavargasri@hotmail.com

${ }^{5} \mathrm{Ph} . \mathrm{D}$. student in Strategic Management Sciences at Colegio Interdisciplinario de Especialización A. C. (CIES) Email: silvitahj@hotmail.com

${ }^{6} \mathrm{Ph} . \mathrm{D}$. student in Strategic Management Sciences at Colegio Interdisciplinario de Especialización A. C. (CIES) Email: efierrod@hotmail.com

${ }^{7} \mathrm{Ph} . D$. student in Strategic Management Sciences at Colegio Interdisciplinario de Especialización A. C. (CIES). Email: lauraorizaba@yahoo.com.mx

${ }^{8} \mathrm{Ph}$. D.-researcher SNI1. UPAEP México. Email: manuel.gonzalez@upaep.mx
}

\begin{abstract}
Coffee consumption habits have evolved along with society for more than 300 years around the world. Social changes imply different lifestyles in each culture. Lifestyles influence the myths used by people in their consumption decisions. The objective of this research is to determine the relationship between lifestyle and coffee consumption habits, from the perspective of myth, in the inhabitants of the Mexican municipalities of Orizaba, Tehuipango, and Zongolica. A survey was conducted with a sample of inhabitants of the three municipalities studied. The statistical analyzes applied were the central limit theorem, Pearson, and Chi-square. The results show that the variables Consumption habits-Lifestyle-Myth, are highly dependent on the level of perception of people. It is concluded that the coffee myth corresponds to the "family union" in the study municipalities. This myth is not characterized in the evolutionary stages contemplated in the "waves of coffee".
\end{abstract}

Keywords-Coffee, Consumption habits, Lifestyle, Myths.

\section{INTRODUCTION}

Consumption habits are a "talk". Roland Barthes defines the "talk" in his book "Mythologies". According to Barthes, "talk" constitutes a semiological system that gives rise to myth. The myth can be linguistic or non-linguistic (Barthes, R., 2010). For example, we must consider history to analyze the lifestyles of people. By knowing the lifestyle of people, it is possible to know the habits of coffee consumption. In this way, the myth is characterized.

Coffee is a beverage that is prepared by infusion. The infusion is made with roasted and ground coffee seed. This definition refers linguistically to the raw material (seed) that is transformed (toast, grind and infuse). The result of the transformation is a liquid suitable for human consumption (drink). However, the Real Academia Española (RAE) also shows definitions such as drunk coffee (breakfast), concert 
coffee (establishment where music is played), Irish coffee (with cream and whiskey), among others. These last definitions have characteristics that are related to social places or with a defined habit of consumption (Real Academia Española, 2017).

Sociology, anthropology, and epidemiology are the sciences that have contributed most to the development of the concept of lifestyles. These sciences define lifestyles as group behavior patterns. Behavioral patterns have a strong influence on the social structure. Lifestyles are composed of habitual reactions and patterns learned in the processes of socialization. The learning is done with parents, classmates, friends, and siblings or by the influence of the school and the media. The learnings are interpreted and applied in diverse social situations. Lifestyles are not fixed, but they present constant changes (Álvarez, L., 2012).

Digital and online innovation is essential in technological change in companies and society. Social networks are alternatives of supply and demand in the digital market. These social networks serve to develop customer loyalty strategies in digital marketing. The most representative social networks are Facebook, YouTube, Twitter, and Instagram. (Quevedo Tacha, P. A., 2017).

"Consumption habits" is a compound word. Its concept is composed of the words "habit" and "consume." The RAE defines "habit" as a special way of proceeding or behaving acquired by repetition of equal or similar acts or originated by inherent tendencies. The same RAE defines "consume" as Using groceries or other goods to satisfy needs or desires. Therefore, consumer habits are unique ways of behaving when using a good. The good has the objective of satisfying needs and desires. These decisions are repeated equally or similarly.

Marketing helps individuals get what they need and want. This help is made through the creation and exchange of products and values. The relations of creation and exchange of value are studied in disciplines such as psychology, neuromarketing, and behaviorism (models of consumer behavior). These models seek to understand what happens in the conscience of the buyer. The buyer's conscience influences the decision to acquire a product or a service. Thus, consumer behavior defines the marketing mix. The marketing mix seeks to position products in the minds of consumers. For example, marketing decisions can be oriented towards design, production volume, distribution, and location. Brain processes explain the behaviors and decision making of consumers. In this way, marketers can make marketing decisions based on consumer behavior. (Torrez, R. et al., 2017; Victoria K. Wells, 2014)

The mass media are a way of transmitting marketing strategies. Television is an essential means of communication. Among others, the advertisements that are transmitted corresponding to the food sector. Not all foods and beverages are considered healthy. However, the content of 'healthy' food advertisements may encourage individuals to build their concept of healthy eating. The changes in diet are associated with the expectation of a modern and "Americanized" diet. This induced perception contributes to the development of health problems. The Caribbean and the Antilles are an example of the trends of diseases related to diet. The most common diseases are diabetes, obesity, hypertension and heart disease. There are also intertwined ecological, economic and social changes that hinder access to a local source of healthy protein (del Castillo, J. A. G., \& Sánchez, C. L., 2017, López-Briones Reverte, C., 2017, Paddock, J. R., 2017).

Cultural aspects are essential to know the elements to which people assign value. Cultural transformation implies that new generations build urban culture and lifestyles. These constructions are made from new practices, representations, and imaginaries about their place of residence and the patrimonial. These representations hinder the homogenization of culture and consumption. Cultural aspects are linked to myth. The myth is a semiological system. Semiology is a tripartite relationship between the signifier the meaning and the symbol. Relationships are a communication system that does not necessarily imply a human being as a sender but as a receiver. Authentic visions are semiological. Thus, myth is a mode of meaning. It is composed of a three-dimensional scheme. The three dimensions are the signifier, the meaning and the sign (Myth). The signifier has sensorial reality (the senses capture it). The meaning is determined by the concept. The concept is built based on history (learning). The sign is the union of the signifier and the meaning. The sign is the myth (Matus, C., 2017, Rapaille, C., 2007, Eco, U., 2016, ZeindPalafox, E., 2017, Barthes, R., 2010).

The objective of this article is to show the relationship that exists between lifestyles and coffee consumption habits. This relationship builds a coffee myth. The myth of the inhabitants of the municipalities of Zongolica, Tehuipango, and Orizaba is studied.

\section{BACKGROUND}

1. The context of coffee consumption.

Coffee is a favorite product and is marketed internationally. Coffee consumption is increasing in the world. Many people consume more than one cup of coffee per day. It is common to have a favorite type of coffee associated with a specific context. The coffee drink has individual sensory characteristics. Also, it is a stimulant due to the caffeine it has. Some research shows that lifestyles cause an increase in the consumption of high-quality coffee. For example, Korean people of the " $\mathrm{Y}$ " generation are those who consume the most high-quality coffee. (Ruiz, LMP, \& Gómez, JAM, 
2017, Spinelli, S. et al., 2017, Kim, D. \& Jang, S., 2017; Sarabia-Peynado, J. \& Vásquez-García, M., 2017).

Soft drinks, energy drinks, and coffee predominate in products with caffeine content. Caffeinated products are widely available in the market. The consumption of products with caffeine is increasing among adolescents. Adolescents consume products with caffeine for reasons of stimulation, pleasant feelings and availability in the market. Adolescents prefer to consume coffee in more diverse social contexts. However, they consume energy drinks in sports contexts and living with friends. Contexts determine the type of beverage with caffeine content (Kim, D., \& Jang, S., 2017; Ludden, A. B, et al., 2017).

Montero Bravo et al. (2006) studied the behavior of eating habits and other lifestyles according to the degree of knowledge that people have about nutrition and dietetics. The results indicated that eating habits are not relevant to the type of food that people choose. However, people choose the type of coffee consumed based on the information they have about the product. Information and education are essential in coffee consumption decisions (Sarabia-Peynado, J. \& Vásquez-García, M., 2017).

\section{Evolution in coffee consumption.}

Coffee has evolved in three stages called "coffee waves." The companies "My Coffee Box" (2017) and "Animal Gourmet" (2014) describe what are considered the three "waves of coffee." Coffee waves also appeared in Mexico, but at different times (Escamilla-Prado \& LanderosSánchez, 2016).

The first wave refers to the way to prepare the drink. The preparation can be soluble, milled or with milk (and its variants). The first wave is socially framed at the end of World War II. The coffee industry privileged the volume of production and low prices. The first stage ends in 1989 in Mexico. Arabica coffee was produced under the classification of "conventional." The International Coffee Organization regulated commercialization. The New York Stock Exchange set the price of coffee in the category of "commodities." Mexican coffee had a lower price due to "poor quality" (Escamilla-Prado, E., Landeros-Sánchez, C., 2016).

The second wave is contextualized in the European industrial revolution. It is characterized by the creation of espresso extraction machines. The espresso machines led to the creation of coffee shops. The cafeterias motivated the distinction of "conventional" and "specialty" coffee. The second wave of coffee appears in Mexico from 1990 to 2010. The way coffee is produced changes. Coffee goes from conventional production to organic production. Coffee gets certifications by particular attributes. The attributes were: organic, fair, friendly with the birds, seal of small producers and sustainable. The coffee grower organizations were incorporated into these forms of production. The leading organizations that participated were from Oaxaca and Chiapas. There is a relationship between the attributes of the packaging and the decision to purchase independent brands in the coffee category. Independent brands compete with leading brands. The visual attributes of packaging can influence the buyer for their choice between leading or independent brands. In the visual attributes of the package, the psychology of the color can influence the purchase preference (Escamilla-Prado, E., Landeros-Sánchez, C., 2016, Aranda, P. A. L., 2017, Rincón Ruiz, C. P., 2017).

Finally, the third wave is characterized by the conscience of the consumer. It assigns importance to the impact of coffee in different dimensions. The dimensions are mainly considered as social, environmental, health and "art" aspects in preparation. The third wave of coffee appears in Mexico as of 2010. Coffee is produced in micro-lots. The lots are formed in quantities of 20 to 150 bags. The coffee drink has extraordinary properties. Coffee is considered a specialty. The baristas and roasters contributed to the formation of the third stage. Current US customers helped the introduction of specialty coffee to different markets (Escamilla-Prado, E., Landeros-Sánchez, C., 2016).

\section{Assessment of coffee consumption.}

The assessment of coffee consumption can be approached from the following aspects: 1) preference of the context; 2) physiological sensitivity to caffeine; 3 ) symbolic attributes. The preference of the context provides information on what is valued in the experience of coffee consumption. The tasters and non-tasters prefer to consume coffee in a social context. Physiological sensitivity refers to the metabolism capacity of caffeine and the number of fungiform papillae. Symbolic attributes are related to culture and can be studied with semiotic tools. People value sensory properties when they metabolize caffeine faster and have fewer fungiform papillae. On the contrary, people value social characteristics when they metabolize caffeine slowly and have a more significant number of fungiform papillae. The symbolic attributes characterize coffee as a specialized product. Specialization is a competitive advantage. For example, Jamaican coffee has characteristics that are considered a competitive advantage. Its competitive advantages help cushion the bargaining power of global coffee buyers (Spinelli, S. et al., 2017, Mighty, M. A., 2017).

The societies have a diversity of consumption. The field of consumer culture addresses the role of ritual processes in consumption. Consumers share moral dispositions and cultural practices. Consumers manipulate ritual processes to distinguish themselves from other consumers. The ritual processes influence the tastes of consumers. The practices performed by people are linked to the social class to which they belong. The new urban middle social classes share 
some qualities inside and outside society. Under this context, everyday coffee consumers are analyzed. There are ethnographic studies about the coffee consumption of knowledgeable people. The studies point to taste as a ritual of transformation. Regular consumers can become knowledgeable consumers because of the taste. The concept of coffee flavor can differentiate between mass consumption and the consumption of connoisseurs. There are studies on coffee from an anthropological perspective. Anthropological studies seek to analyze the dimensions covered by the "coffee world." Television offers ads related to coffee. The anthropological analysis can be done considering the context of television programming. The context of the programming conditions the perceptions of the coffee spectators. The programming context includes cultural aspects of the viewers (Shaker-Ardekani, R., \& Rath, J., 2017, Quintão, RT, et al., 2017, Sherry Jr, J. F., 1995).

4. Cross perception, characteristics and sensory properties of coffee.

Some studies deal with perception. A perception technique is cross perception. Cross perception research can be useful for people who prepare coffee. The baristas can use the information to decide the presence of the coffee and transmit a message according to the expectations of the consumer. This technique serves to investigate interactions between different sensory modalities. The relationships between taste and expectations serve to study the perception of the coffee consumer. These studies can be done in a multicultural way. An example is the study of cross perception that was carried out with people from China, Colombia, and the United Kingdom. The results indicated that people expect aromatic coffee in cups with a little diameter. People also expect coffee to be more bitter and intense in small cups. On the contrary, people expect coffee to be sweeter in larger diameter cups. The results are also related to aspects of culture. Participants in the United Kingdom expect coffee cups to be hotter (George Van Doorn et al., 2017).

The third wave of coffee involves the consumption of highend coffee or premium coffee. A high-end coffee is one that has information about production processes, sensory, social and functional characteristics, health benefits, origin. Highquality coffee is consumed in exclusive coffee shops. The consumption of high-end coffee is studied from the aspect of value creation and capital accumulation. The accumulation of capital is a characteristic of neoliberal globalization. Neoliberalism studies the creation of value from social and economic theories. Social and economic theories study the production and extraction of surplus value through global trade. Toast and baristas create surplus value when they develop a new quality lexicon for coffee. The surplus value is one of the best ways to generate value for money in the coffee market. The perception of luxury value motivates the consumption of high-quality coffee. Luxury value is characterized by materialism, conformity, visible trends and functional dimensions. Surplus value uses social and cultural capital in the creation of symbols. The surplus value of coffee confirms the classic patterns of dependence on the accumulation of global capital (Fischer, E. F., 2017, Sarabia-Peynado, J., \& Vásquez-García, M., 2017; Kim, D. \& Jang, S., 2017).

There is a generation of people called Millenials. Millennials look for new experiences. Value-added products produce new experiences and social status. International trade is a new shopping experience. Electronic commerce allows transactions with few intermediaries. With e-commerce, it can buy premium products. Social status is a privilege derived from the consumption of premium products. The perception of coffee depends on the context. However, the willingness of consumers to acquire products with ethical attributes does not always translate into real purchases. One cause of this result is the consumer's lack of credibility that the product has ethical attributes. Some current perceptions are: coffee is a beverage that accompanies it to close the most important business of life. Coffee can help to feel better; coffee helps live with the people in harmony, coffee is a social network without ICTs (Sarabia-Peynado, J. \& Vásquez-García, M., 2017; Ruiz, LMP, \& Gómez, JAM, 2017; Carlos Montero et al., 2013).

\section{RESEARCH METHODOLOGY}

Myths are convictions that people have about a specific topic. These convictions depend on the perception that people have of the phenomenon in question. Perception is based on processes of experience, culture, and learning. Thus, myths are the appropriate sociological tool for studying the behavior of coffee consumers.

The structure proposed by Roland Barthes is used to study the myth of coffee that consumers have. The author proposes a system of three elements: Meaningful (symbol), Meaning, Myth. In the present study, the signifier is approached with the study of consumption habits. The meaning is studied with the lifestyles of people (Fig.1: Methodology to structure the myth of coffee). The myth is the relationship that exists between lifestyle and coffee consumption habits. The myth is also complemented by what people think about coffee. The sample consisted of 27 people. The municipalities considered were Zongolica, Orizaba, and Tehuipango. The distribution was as follows: 6 people based in Zongolica; 5 people based in Orizaba; 16 people based in Tehuipango.

The measuring instrument used was the questionnaire. The questionnaire used Likert questions. 
The technique of application of the questionnaire was the interview. The statistical tests that were used were the
Central Limit Theorem, Vertical Pearson Correlation, Frequency Distribution and Chi-square.
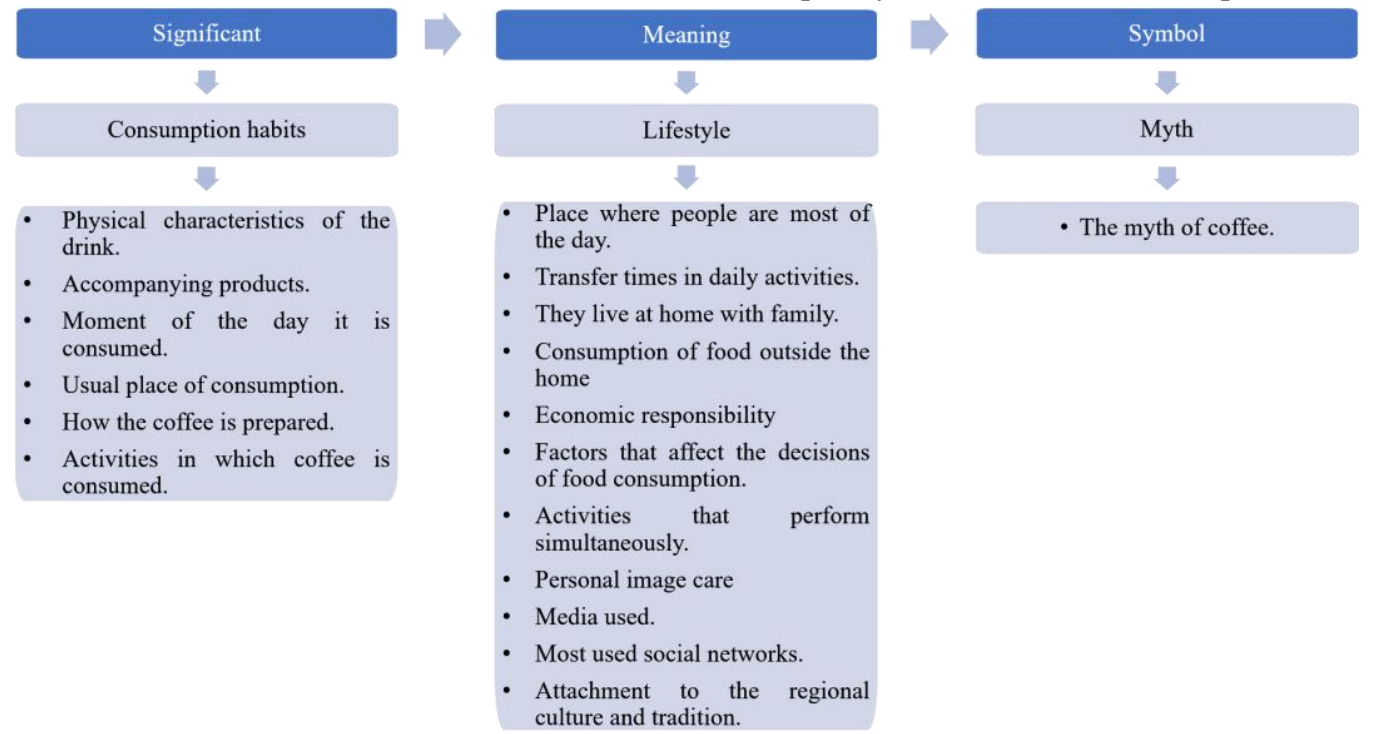

Fig.1: Methodology to structure the myth of coffee.

\section{RESULT AND DISCUSSION}

The data showed a normal distribution based on the Central Limit Theorem. There was a variation of 0.14 only in the straight average of the general database (Table 1).

Table.1: Proof of normality with the Central Limit Theorem.

\begin{tabular}{|l|c|c|c|}
\hline \multicolumn{4}{|c|}{ Central Limit Theorem } \\
\hline Municipality & $\begin{array}{c}\text { Population } \\
\text { average. }\end{array}$ & $\begin{array}{c}\text { Vertical } \\
\text { average. }\end{array}$ & $\begin{array}{c}\text { Horizontal } \\
\text { average. }\end{array}$ \\
\hline General & 2.85 & 2.85 & 2.99 \\
\hline Orizaba & \multicolumn{3}{|c|}{2.80} \\
\hline Tehuipango & \multicolumn{3}{|c}{2.84} \\
\hline Zongolica & \multicolumn{3}{|c}{2.83} \\
\hline
\end{tabular}

Table 2 shows the correlations obtained in Pearson's vertical correlation analysis.

Table.2: Vertical correlation of Pearson.

\begin{tabular}{|l|l|}
\hline \multicolumn{2}{|c|}{ Vertical Pearson Correlation } \\
\hline $\begin{array}{l}\text { Correlation } \\
\text {-Item vs. } \\
\text { Item }\end{array}$ & \multicolumn{1}{|c|}{ Correlated items } \\
\hline \multicolumn{1}{|c|}{ Consumption Habits (CH) } \\
\hline $\begin{array}{l}0.75-\text { CH1m } \\
- \text { CH1k }\end{array}$ & $\begin{array}{l}\text { The coffee I drink is covered with } \\
\text { chocolate chips/whipped cream/ice cream- } \\
\text { CORRELATED WITH-The coffee I drink } \\
\text { is Latte. }\end{array}$ \\
\hline $\begin{array}{l}\text { 0.81- CH1m } \\
- \text { CH11 }\end{array}$ & $\begin{array}{l}\text { The coffee I drink is covered with } \\
\text { chocolate chips/whipped cream/ice cream- } \\
\text { CORRELATED WITH-The coffee I drink } \\
\text { has another added flavor. }\end{array}$ \\
\hline
\end{tabular}

\begin{tabular}{|c|c|}
\hline $\begin{array}{l}0.74-\mathrm{CH} \\
-\mathrm{CH} 1 \mathrm{~m}\end{array}$ & $\begin{array}{l}\text { When I drink coffee I accompany it with } \\
\text { pastry/cake-CORRELATED WITH- The } \\
\text { coffee I drink is covered with chocolate } \\
\text { chips/whipped cream/ice cream. }\end{array}$ \\
\hline $\begin{array}{l}0.72-\mathrm{Cl} \\
-\mathrm{CH} 1 \mathrm{k}\end{array}$ & $\begin{array}{l}\text { The way to prepare the coffee I drink is in } \\
\text { capsule coffee machine-CORRELATED } \\
\text { WITH-The coffee I drink is Latte. }\end{array}$ \\
\hline $\begin{array}{l}0.78-\mathrm{CH} 4 \mathrm{e} \\
-\mathrm{CH} 4 \mathrm{~d}\end{array}$ & $\begin{array}{l}\text { The way to prepare the coffee I drink is in } \\
\text { capsule coffee machine-CORRELATED } \\
\text { WITH-The best place where I drink coffee } \\
\text { is in Cafes. }\end{array}$ \\
\hline $\begin{array}{l}0.7-\mathrm{CH} 6 \mathrm{c}- \\
\mathrm{CH} 4 \mathrm{~b}\end{array}$ & $\begin{array}{l}\text { The people I drink coffee with is family- } \\
\text { CORRELATED WITH-The best place } \\
\text { where I drink coffee is at Home. }\end{array}$ \\
\hline $\begin{array}{l}0.83-\mathrm{CH} 7 \mathrm{~b} \\
-\mathrm{CH} 4 \mathrm{a}\end{array}$ & $\begin{array}{l}\text { I drink coffee when I move- } \\
\text { CORRELATED WITH-The best place } \\
\text { where I drink coffee is when I move. }\end{array}$ \\
\hline & \\
\hline $\begin{array}{l}0.7-\text { LS13c- } \\
\text { LS11 }\end{array}$ & $\begin{array}{l}\text { The social network that I use the most is } \\
\text { Whatsapp-CORRELATED WITH-I take } \\
\text { care of my image. }\end{array}$ \\
\hline $\begin{array}{l}0.77-\text { LS13c } \\
\text { - LS12b }\end{array}$ & $\begin{array}{l}\text { The social network that I use the most is } \\
\text { Whatsapp-CORRELATED WITH-The } \\
\text { most used means of communication is a } \\
\text { cell phone with internet. }\end{array}$ \\
\hline & Myth (My) \\
\hline $\begin{array}{l}0.79-\text { Mylh } \\
\text { - My1g }\end{array}$ & $\begin{array}{l}\text { Coffee is Wisdom-CORRELATED } \\
\text { WITH-Coffee is meditation. }\end{array}$ \\
\hline \multicolumn{2}{|c|}{ Consumption Habits (CH)- Lifestyle (LS) } \\
\hline $\begin{array}{l}0.79-\mathrm{LS} 3- \\
\mathrm{CH} 4 \mathrm{~b}\end{array}$ & $\begin{array}{l}\text { I live at home with my fa } \\
\text { CORRELATED WITH-The best } \\
\text { where I drink coffee is at Home. }\end{array}$ \\
\hline
\end{tabular}


Table 3 shows the level of sensitivity of the variables with the Chi-square analysis.

Table.3: Analysis of Chi-square.

\begin{tabular}{|c|c|c|c|}
\hline \multicolumn{4}{|c|}{ Chi-square analysis $(\mathbf{p}=\mathbf{0 . 5})$} \\
\hline $\begin{array}{c}\text { Degrees } \\
\text { of } \\
\text { freedom. }\end{array}$ & $\begin{array}{c}\text { Chi } \\
\text { calculated. }\end{array}$ & $\begin{array}{c}\text { Chi } \\
\text { observed. }\end{array}$ & Interpretation. \\
\hline 284 & 1215.86 & 324.31 & $\begin{array}{c}\text { The variables } \\
\text { are highly } \\
\text { dependent on } \\
\text { the level of } \\
\text { (71 rows } \\
\text { and four } \\
\text { columns }\end{array}$ \\
& & & $\begin{array}{c}\text { appreciation of } \\
\text { the people. }\end{array}$ \\
\hline
\end{tabular}

Fig. 2 presents the results in coffee consumption habits. Fig. 3 presents the results of the lifestyle of people. Fig. 4 shows the myths with which people relate to coffee.

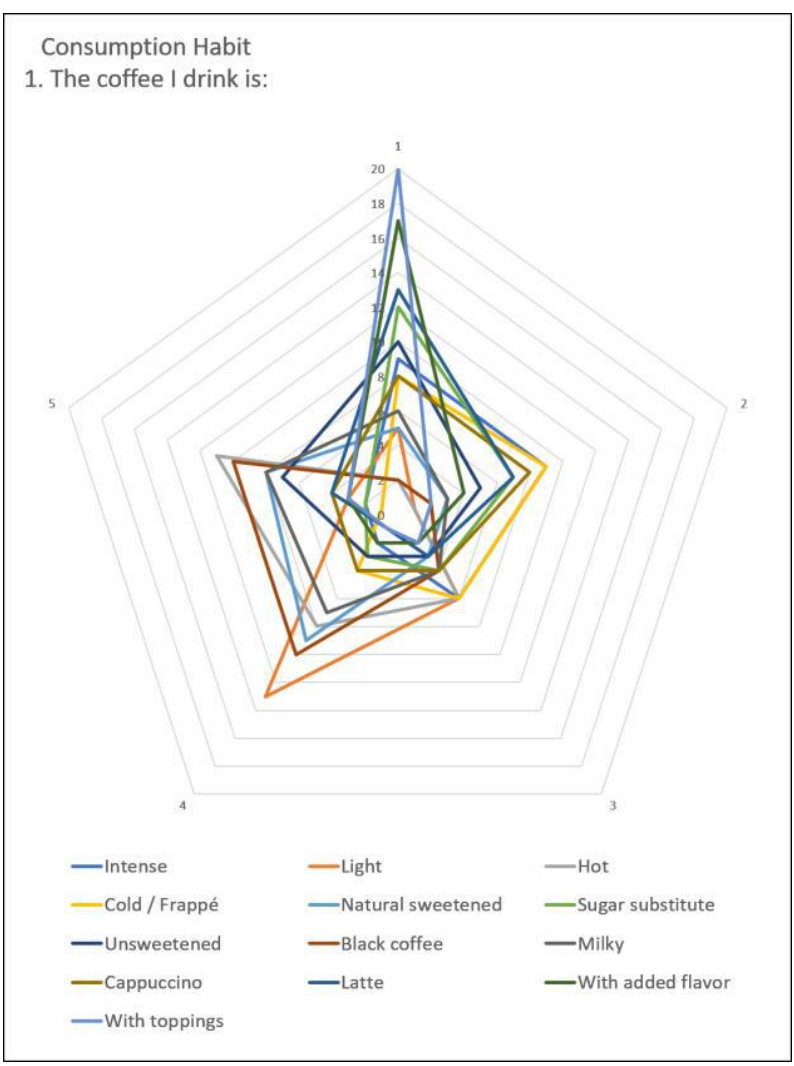

Consumption Habit

2. When I drink coffee I accompany it with:

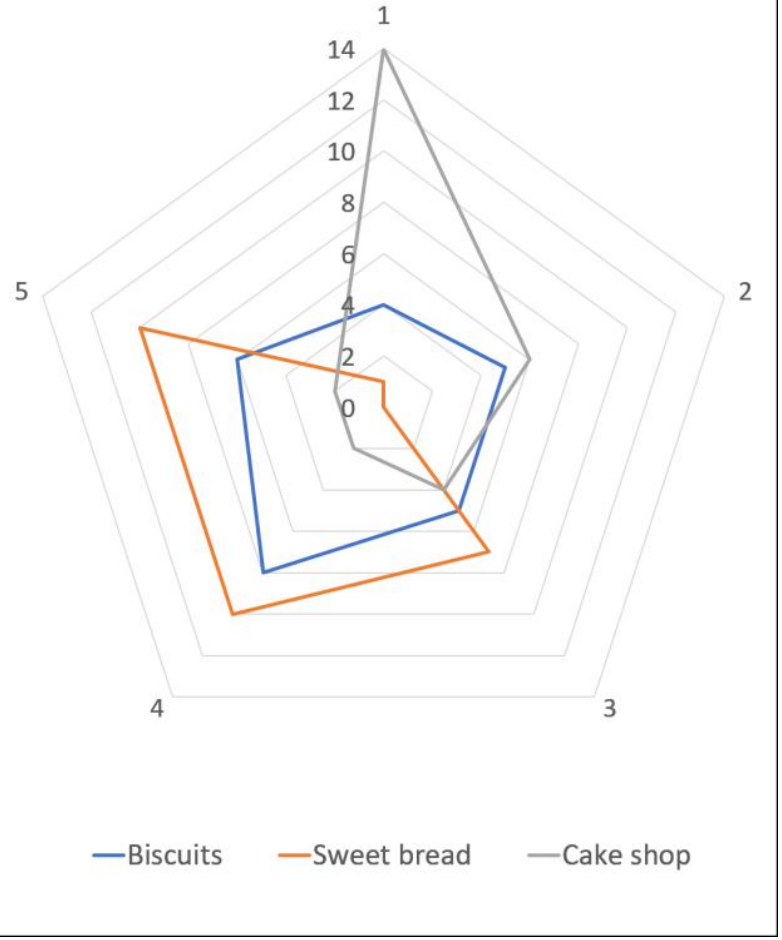

Consumption Habit

3. The best time to drink coffee is:

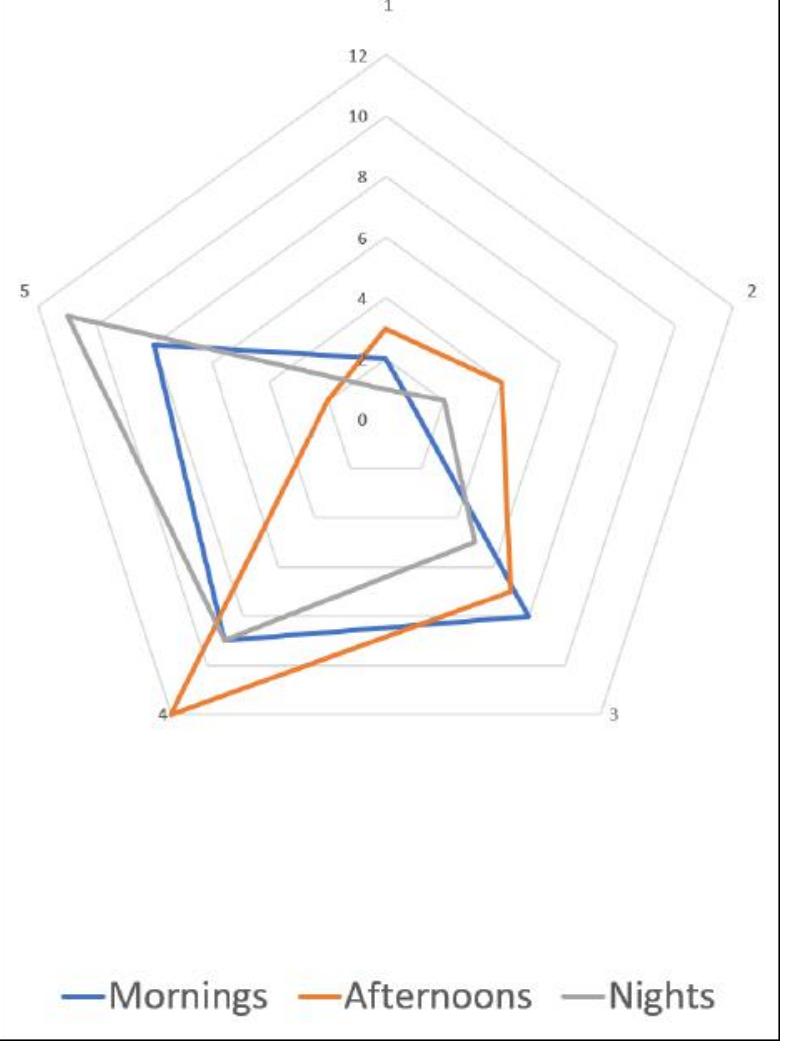



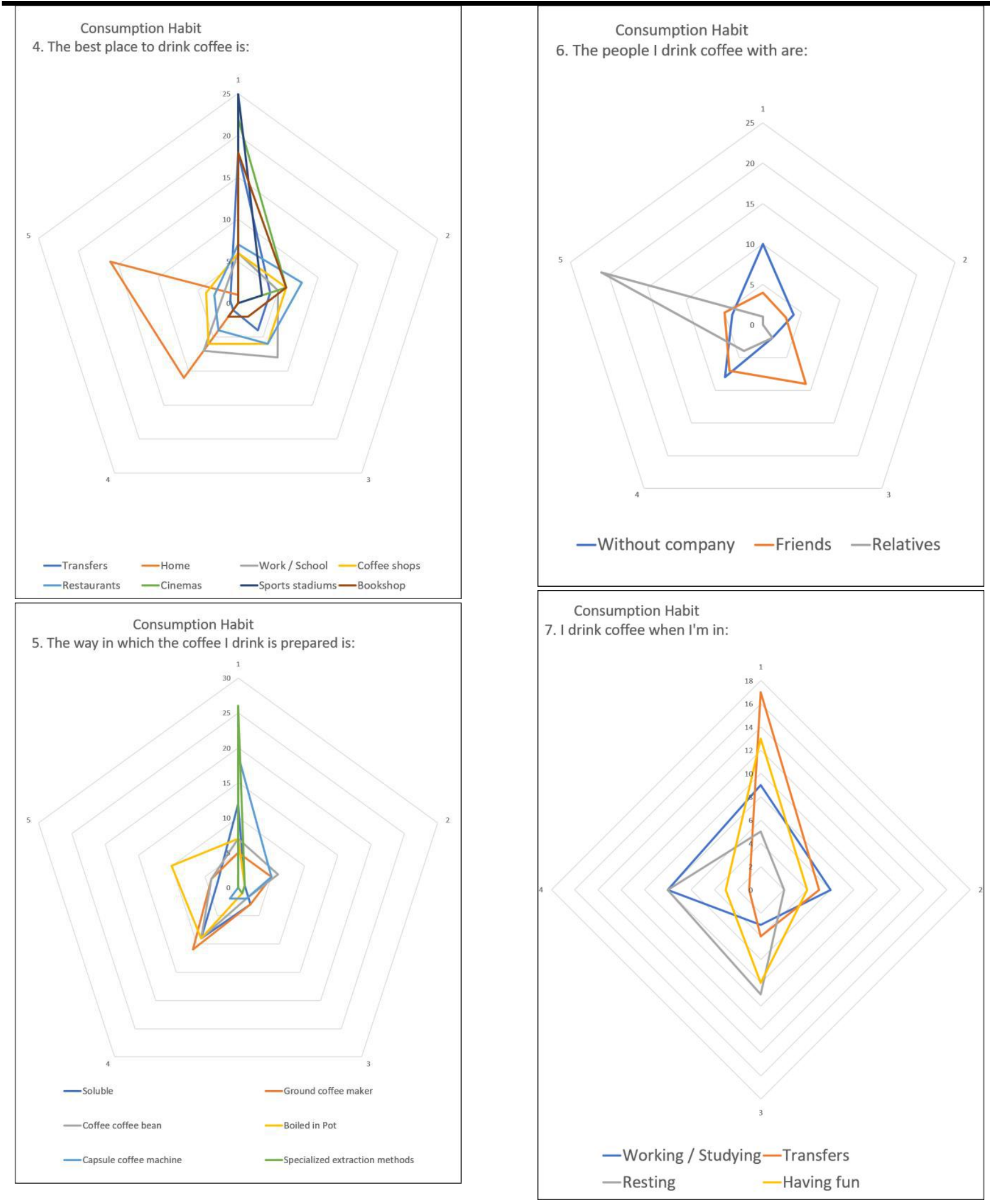

Fig.2: Preference in coffee consumption habits. 


\section{Lifestyle}

1. Most of the day I am in:

2. Transfer times in daily activities:
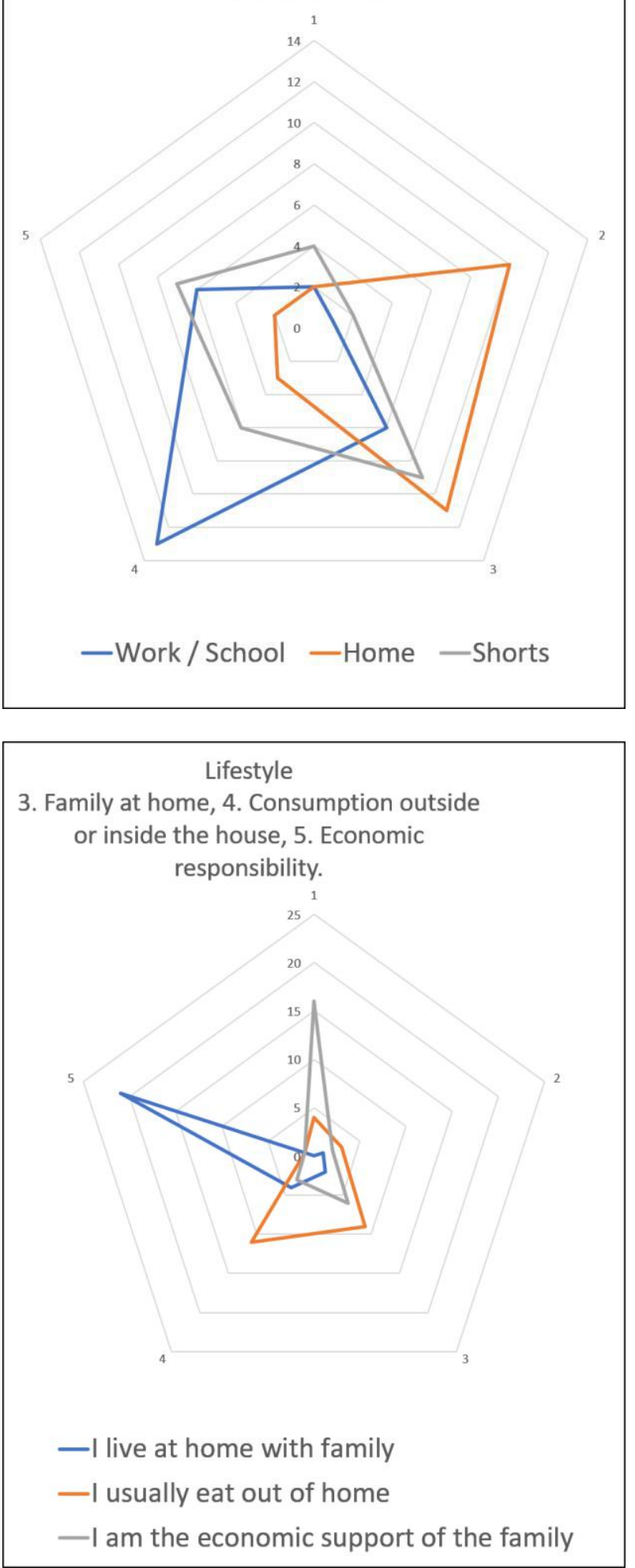

\section{Lifestyle}

6. Influence on food consumption, 7. Simultaneous activities.

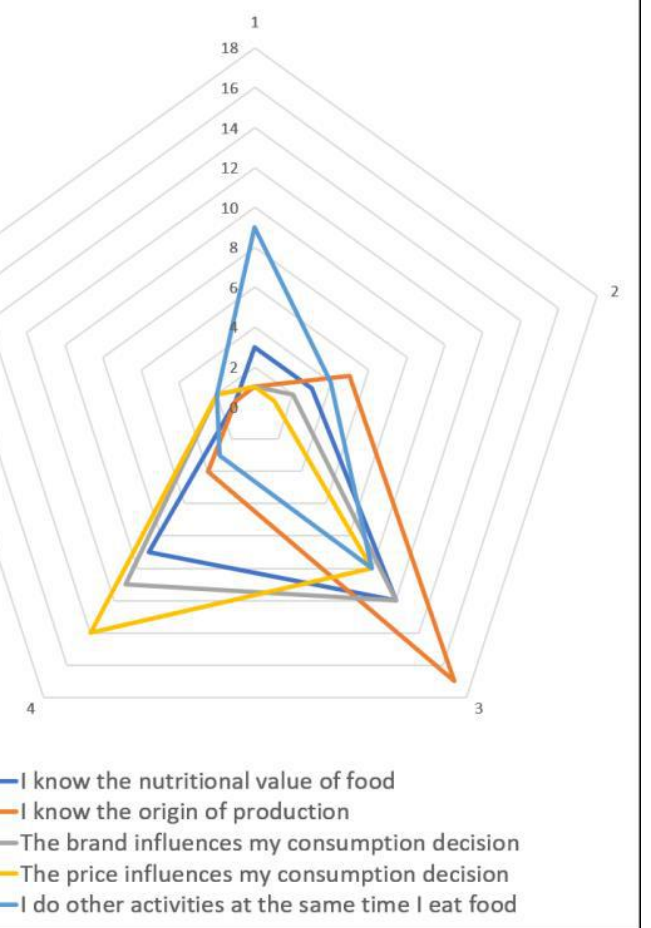

- The price influences my consumption decision

- I do other activities at the same time I eat food

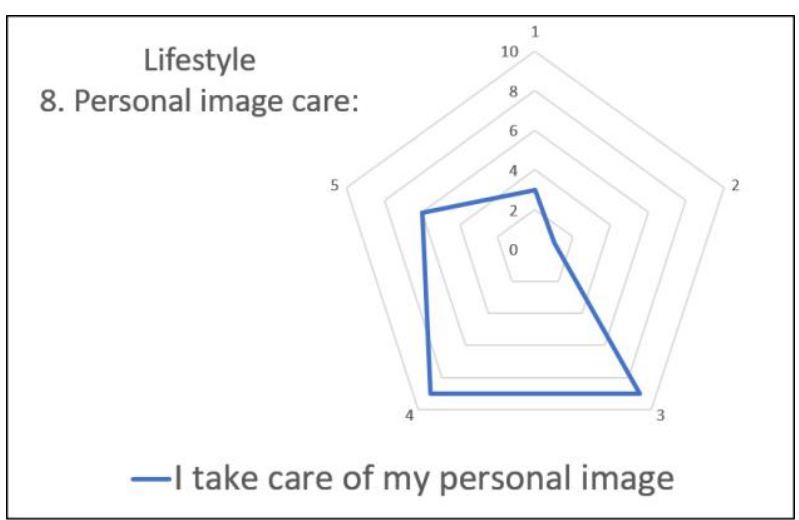

Lifestyle

9. Attachment to regional culture and 1 tradition:

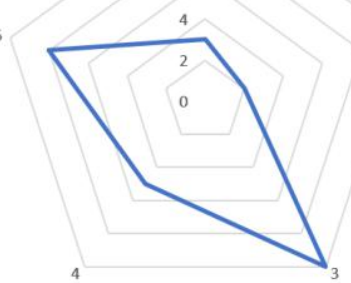

- I am attached to the traditions and customs of my region 


\section{Lifestyle}

10. Most used social networks:

-TV

Cell phone with internet

Laptop with internet

Tablet with internet

- Radio

-Facebook

-Twitter

-Whatsapp

- Instagram

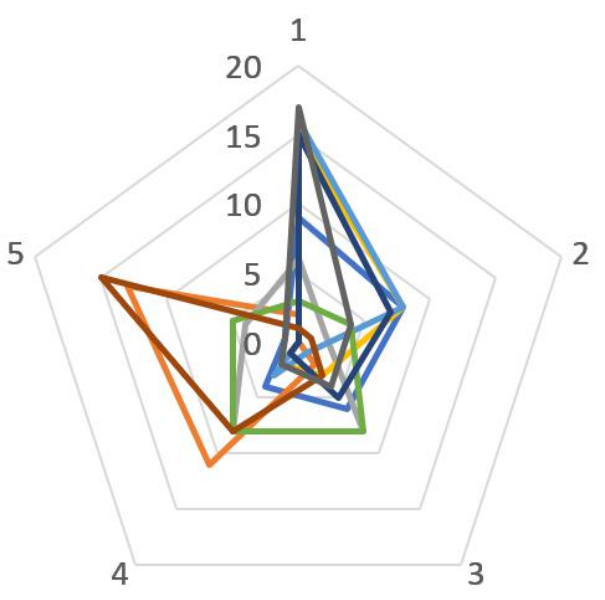

Fig.3: Predominant elements in the lifestyle of people.

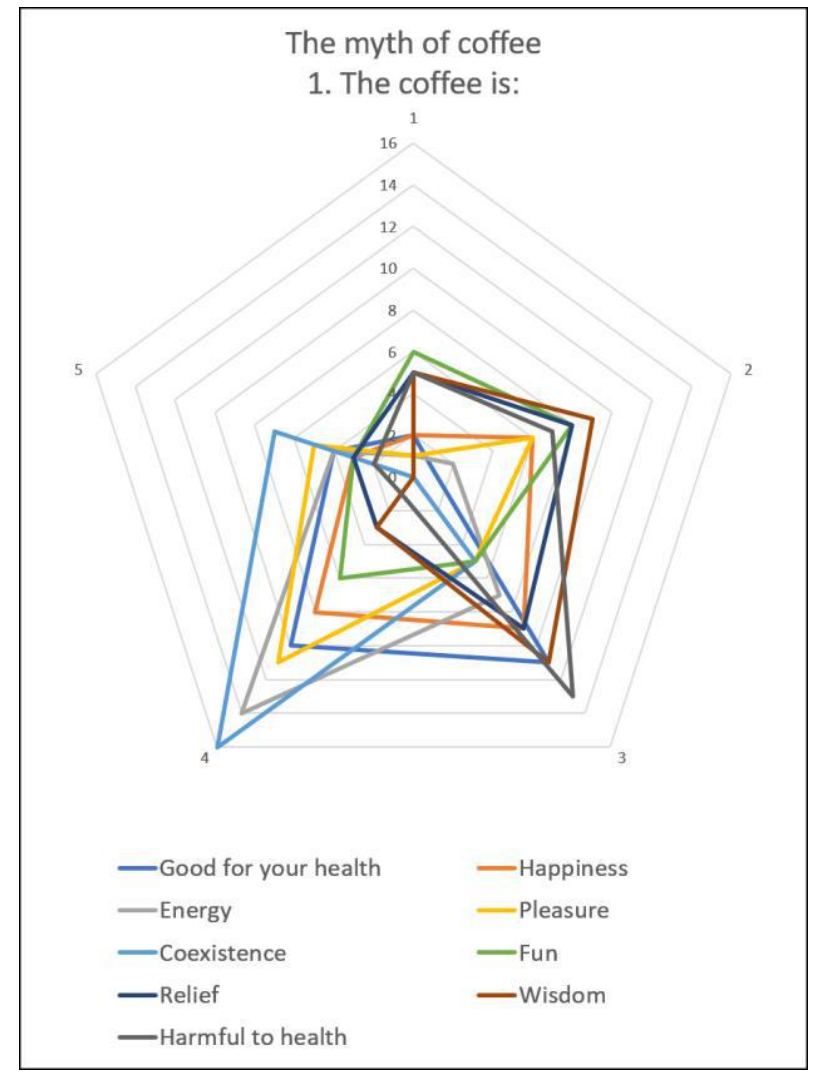

Fig.4: Myths with which it is commonly associated with coffee.

With the tables and figures that are shown, it is possible to make inferences based on the study variables. The first analysis corresponds to coffee consumption habits. Consumers drink coffee practically all day, however, prefer to drink it more often in the evenings and nights. The home is the favorite place to drink coffee with family members. People usually rest when they drink coffee. The characteristics of the drink are black coffee, hot, light and naturally sweetened. People prefer to accompany coffee with sweet bread and cookies. The coffee is prepared mainly soluble, in coffee pots ground and boiled in a pot.

The second analysis is related to the lifestyle of people. Individuals spend most of their time at work or school. The time of transfer from their homes to their work/school is short. Most people live with their families and do not have the main economic responsibility in their homes. People usually eat outside the home and at the same time perform other activities. Individuals do not know the nutritional value of their food, but the origin of production. The price and the brand constitute relevant elements in the decisions of purchase and consumption. Individuals give value to the care of the personal image. The roots of the traditions and culture of the region show heterogeneity in the population. WhatsApp is the most used social network. The use of mobile phones with internet access is preferred for communication.

The third analysis corresponds to the myth. Coffee is mainly related to positive attributes. However, respondents think that coffee can be harmful to health.

\section{CONCLUSION}

The analysis of the results shows that the characterization of the coffee myth is involved in the inhabitants of the municipalities analyzed.

The signifier (Consumption Habits) is hot, black, sweet (natural) coffee and accompanied by bread or cookies.

The meaning (Lifestyle) is the family. Coffee unites work and family environments. People are influenced by communication technologies, social networks and the transformation of culture.

The family unit is the myth of coffee for the inhabitants of the municipalities analyzed. This myth is not characterized in the evolutionary stages contemplated in the "waves of coffee."

The global trends in coffee preparation and consumption are not relevant in the municipalities studied. 
The results can serve as support for the development of marketing strategies for coffee in the area.

\section{ACKNOWLEDGEMENTS}

To the coffee growers of the Zongolica region, for the support and confidence in the coffee promotion activities. To the Instituto Tecnológico Superior de Zongolica, for the facilities for the development of the research projects.

To the Colegio Interdisciplinario de Especialización A.C., for advice and follow-up on doctoral activities.

\section{REFERENCES}

[1] Álvarez, L. S. (2012). Los estilos de vida en salud: del individuo al contexto. Revista Facultad Nacional de Salud Pública, 30(1), 95-101.

[2] Animal Gourmet. (2014). Las olas históricas del café. Retrieved from http://www.animalgourmet.com/2014/07/09/las-olasdel-cafe/

[3] Aranda, P. A. L. (2017). Influencia de los atributos del empaque en la decisión de compra de marcas propias en productos de café. Working Papers. Maestría en Gerencia Estratégica de Mercadeo, 2(1).

[4] Barthes, R. (2010). Mitologías. México: Grupo Editorial Siglo XXI.

[5] Carlos, A.-G., Montero-Simó, M. J., Araque-Padilla, R. Á., \& Gutiérrez-Gutiérrez, L. (2013). Evaluación del valor percibido en el consumo de café con atributos éticos. Agrociencia, 195-207.

[6] del Castillo, J. A. G., \& Sánchez, C. L. (2017). Medios de comunicación, publicidad y adicciones. EDAF.

[7] Eco, U. (2016). Tratado de semiótica general. México: Penguin Random House Grupo Editorial.

[8] Escamilla Prado, E., y Landeros Sánchez, C. (2016). Cafés diferenciados y de especialidad. Huatusco: Códice/Servicios Editoriales.

[9] Fischer, E. F. (2017). Quality and inequality: Taste, value, and power in the third wave coffee market (No. 17/4). MPIfG Discussion Paper.

[10] George Van Doorn, Andy Woods, Carmel A. Levitan, Xiaoang Wan, Carlos Velasco, Cesar Bernal-Torres, Charles Spence, Does the shape of a cup influence coffee taste expectations? A cross-cultural, online study, In Food Quality and Preference, Volume 56, Part A, 2017, Pages 201-211, ISSN 0950-3293, https://doi.org/10.1016/j.foodqual.2016.10.013.

[11] Kim, D., \& Jang, S. (2017). Symbolic consumption in upscale cafés: Examining Korean gen Y consumers' materialism, conformity, conspicuous tendencies, and functional qualities. Journal of Hospitality \& Tourism Research, 41(2), 154-179.
[12]López-Briones Reverte, C. (2017). Construcción del concepto de alimentación saludable a través de la publicidad, España 1960-2013.

[13] Ludden, A. B., O'Brien, E. M., \& Pasch, K. E. (2017). Beliefs, Behaviors, and Contexts of Adolescent Caffeine Use: A Focus Group Study. Substance Use \& Misuse, 1-12.

[14] Matus, C. (2017). Estilos de vida e imaginarios urbanos en nuevos residentes de Lastarria y Bellas Artes: el barrio patrimonial como escenario de diversidad, distinción y movilidad. EURE (Santiago), 43(129), 165-186.

[15] Mighty, M. A. (2017). "We Likkle, but We Tallawah": Maintaining Competitive Advantage in the Crowded Specialty Coffee Market. Journal of International Food \& Agribusiness Marketing, 29(1), 70-91.

[16] Montero Bravo, A., Úbeda Martín, N., \& García González, A.. (2006). Evaluación de los hábitos alimentarios de una población de estudiantes universitarios en relación con sus conocimientos nutricionales. Nutrición Hospitalaria, 21(4), 466-473. Retrieved from http://scielo.isciii.es/scielo.php?script=sci_arttext\&pid $=$ S0212-16112006000700004\&lng=es\&tlng=pt.

[17] My Coffee Box. (14 de julio de 2017). Las olas del café en la historia. Retrieved from https://mycoffeebox.com/las-olas-del-cafe-la-historia/

[18]Paddock, J. R. (2017). Changing consumption, changing tastes? Exploring consumer narratives for food secure, sustainable and healthy diets. Journal of Rural Studies, 53, 102-110.

[19]Quevedo Tacha, P. A. (2017). Influencia del marketing digital y online en la fidelización de los clientes de consumo masivo: categoría chocolatinas.

[20] Quintão, RT, Brito, EZ \& Belk, RW (2017). The taste transformation ritual in the specialty coffee market. SAR: Journal of Business Administration , 57 (5), 483494. : 10.1590 / S0034-759020170506

[21]Rapaille, C. (2007). The culture code. New York: Crown Business.

[22]Real Academia Española. (2017). Retrieved from http://dle.rae.es/?id=6bQcjCM

[23]Rincón Ruiz, C. P. (2017). Psicología del color, su importancia e influencia en la decisión de compra del consumidor: un enfoque desde el sector de alimentos y bebidas en Colombia (Bachelor's thesis, Universidad Militar Nueva Granada).

[24]Ruiz, L. M. P., \& Gómez, J. A. M. (2017). Factores principales para vender café en China a través del ecommerce. Ploutos, 6(1), 46-55.

[25] Sarabia Peynado, J., \& Vásquez García, M. (2017). Estrategias para incrementar el consumo de cafés especiales en Colombia. 
[26] Shaker Ardekani, R., \& Rath, J. (2017). Coffee people in Tehran, Glasgow and Amsterdam. Journal of Consumer Culture, 1469540517736557.

[27] Sherry Jr, J. F. (1995). Bottomless cup, plug-in drug: A telethnography of coffee. Visual Anthropology, 7(4), 351-

370.http://www.tandfonline.com/doi/abs/10.1080/089 49468.1995.9966660

[28] Spinelli, S., Dinnella, C., Masi, C., Zoboli, G. P., Prescott, J., \& Monteleone, E. (2017). Investigating preferred coffee consumption contexts using openended questions. Food Quality and Preference, 61, 6373.

[29] Torrez, R., Esperanza, L., Morales, E., \& Guadalupe, H. (2017). Estudio del comportamiento del consumidor: Comportamiento del consumidor a la hora de comprar (Doctoral dissertation, Universidad Nacional Autónoma de Nicaragua).

[30] Victoria K. Wells (2014) Behavioural psychology, marketing and consumerbehaviour: a literature review and future research agenda, Journal of Marketing Management,30:11-12, 1119-1158, DOI: 10.1080/0267257X.2014.929161

[31]Zeind-Palafox, E. (2017). Semiótica, puente entre la Mercadotecnia y la Publicidad. Retrieved from https://donpalafox.blogspot.mx/2017/07/semioticapuente-entre-la-mercadotecnia.html 